Mare Matthew- PhD Student systematic theology (UNISA), Master of Human Rights, Peace and Development (AU), Masters in Strategic Communication (WUA), Master of Religious Studies (UZ), Master Peace, Leadership and Conflict Resolution (ZOU), Master of Developmental Studies (WUA), Honours in Religious Studies (UZ), Part Time Honours in Political Science (UZ) and 12 Executive certificates in various fields. Mare is also National Aids Council, Board Member and specialises in Human Security researches. 64051420@mylife.unisa.ac.za

\title{
Politics of rule of law: A human and state security perspective in the case of Zuma
}

\begin{abstract}
This research is a desktop research that, looks at the ligament that connects politics of rule of law, human security and state security perspectives in the case of Zuma. The study looked at various framing and diverging interpretations of Zuma's case by the various sections of South Africa. Some sections of the society especially the Zulu and Malema believed that, Zuma's case is a continuation of apartheid politics and is targeted at the Zulu tribe who were the most vocal during war against Apartheid. From the perspective of the principle of the rule of law the law was applied without fear or favour. Former president Thabo Mbeki was concerned about timing as he believed that there was no urgency in handing inn the arrest warrant. Mbeki projected that, the judgement can result in loss of lives and property. Mbeki believed that, Ramaphosa should not pride himself in succeeding to jail Zuma but should look beyond the act. The study noted the human security dimension where the Zuma case is merely a scapegoat by already agitated general populace. From a security perspective the study noted that, the Bantustan revolution is not far from being imminent. The Zulu have for long been indoctrinating their children and forming regiments to prepare a reclamation of Zulu empire. Even the education in KwaZulu Natal prepares children to pursue the dream of the restoration of the Zulu empire. The role of agitated foreigners and illegal immigrants who crossed to South Africa in anticipation of sustainable livelihoods only to be othered and subjected to xenophobic attacks. The violence presents an opportunity for them to loot and also to fight for a better South Africa since they do not harbour any prospective of turning to their countries anytime soon, South Africa is now their own country and any developments in the country affects them directly. Since political determination is through the ballot box a key aspect, limited to citizens. Non-citizens regard themselves as both de facto and de jure citizen Streets demos presents an opportunity for the non-voting constituency push for their human security needs. The study in light of the foregoing proposed case scenarios of the likelihood outcomes.
\end{abstract}




\section{Introduction}

World over the debates alternates between judicial state capture and judicial independence especially when the judgement does not favour a section of the society or a larger population. Some section aligned to the Zulu tribe believe that, the judgement is a continuation of Apartheid politics by Apartheid remanences within South Africa's judicial system. The same section believes that, some ANC senior members and president Ramaphosa are working in cahoots with the Apartheid judicial system under the disguise of rule of law inorder to punish Zuma who is suspected of influencing Magashule to fire Ramaphosa and replaced him with Lindiwe Zulu. The Zuma case has digressed from being a legal matter to politics of checkmate or fight to finish. Whilst it is the right of the citizens to challenge or demonstrate against a perceived targeted piece of legislation or court judgements, such right must be exercised peacefully. There are a number of case laws where the state is empowered to put restrictive measures in case of human and state security concerns. The legitimate aim of the street demonstrators of wanting to remove a sitting president and forcefully arm-twist the state to violate the Constitution to remove a convict was found to be setting a wrong legal precedence. Meanwhile, failure to take heed of the streets may also ignite serious popular revolt. The study, believes that, there are a number of political hidden variables to Zuma's case. In conflict resolution studies, the root tree theory demand that, when responding to any conflict one must investigate both hidden and open reasons to a conflict. Zuma case is highly complex with the potential of causing or influencing regime alteration, with president Ramaphosa likely to be recalled or impeached.

\section{Background}

The rule of law doctrine's key emphasis is on the equality of law and before the law respective of one's creed, position, culture amongst other. The rule of law doctrine deals with the quality of the law in a country. The rule of law doctrine resonates with South Africa's Constitutional Bill of Rights provisions. The politics of the rule of law is in this case an attempt to arm-twist this doctrine for political expedience. Zuma's case is a simple case of contempt of court and the law applied inline with the dictates of the rule of law and not rule by law. The issue of equality is the key aspect in South Africa's Bill of Rights. Chapter 2, Section 7-39 of South Africa's Constitution contain the Bill of Rights that is a cornerstone of democracy in South Africa and it enshrine invariable rights of all people without prejudice (Constitution of South Africa, Chapter 2 Section 7-39:1999). Globally both sitting and former presidents are convicted and appear before the courts. Charles Taylor the former president of Liberia was convicted and 
sentenced by the International Criminal Court (ICC), the ICC once issued a warrant of arrest for Kenyan president and his vice president Kenyatta and Ruto respectively, in Zambia the Chiluba and Mwanawasa case, in Egypt the Mubarak case amongst others are key examples. It is not like the arrest of Zuma is history breaking and what might be perhaps history making is the interplay between rule of law, human and state security dimension.

In this case violating the rule of law doctrine sets a very bad legal precedence. In the history of Constitutional hurdles, the Madzimbamuto case is widely referred to and the Zuma case is likely going to be another constitutional nightmare. In South Africa the Constitutional Court has never before set aside or rescinded its own orders. However, the protestors are pinning their hope on the appeal and they have already acquitted him before he even appears before the courts. The danger is on failure to deliver the judgement same day, because given the nature of the case it might require that the judgement be reserved so that judges takes their time to study the merit of the case. Whilst this position makes a legal sense it poses a serious threat to both national and human security. The protestors have already taken law into their own hands. The politics of rule of law is at play.

However, on the other hand protestors strongly believe that, Zuma was unfairly treated and that his judgement is more political and apartheid as opposed to adherence to the rule of law principle. This dovetails with Section 9 of the Constitution which guarantees the right of every person not to be unfairly discriminated against, directly or indirectly, on the basis of race, gender, sex, pregnancy, marital status, ethnic or social origins, colour, sexual orientation, age, disability, religion, conscience, belief, culture, language. There is a sense in which Zuma was unfairly treated because of his ethnicity, race and his political exposé of fighting Apartheid and neo-Apartheid in South Africa. The ANC, Ramaphosa, the Judiciary and Zuma have all the burden of proof, Zuma must prove beyond reasonable doubt that his discrimination was unfair. Legally, discrimination is not a crime but it only become unfair if it violates one or more of the stated conditions. Meanwhile, ANC, Ramaphosa and the Judiciary has the duty to prove that, discrimination did not take place. Airing the judicial proceeding is another way of solving this legal dilemma, a strategy used in Zimbabwe to solve an electoral dispute between opposition leader Nelson Chamisa and president Mnangagwa in 2018. South Africans need to be engaged as opposed to hard law responses by the state. The basic principle of any law is that, justice must be seen to be done. 
The South African courts have a self-preservation mechanism, to protect itself from abrogation. The South African courts are immune to undue influence and Section 8 of South African Constitution states that, the judicial authority of the Republic is vested in the courts. Second most important aspect, the courts are independent and subject only to the Constitution and the law, which they must apply impartially and without fear, favour or prejudice (Constitution of South Africa, Section 8:1999). The political talk that ANC or Ramaphosa influenced the court decision is a political statement that is legally unsustainable when one considers how South African courts functions. It will be utopia to talk of ANC or Ramaphosa influencing judicial proceedings in South Africa. The South African government moved from one extreme to the other, it moved from extreme Apartheid to extreme democracy, far that the president and political parties are merely public senior servants. In some cases, the president is so vulnerable that, he can't make an absolute decision fearing to be recalled. There is no Executive presidency in South Africa. Thomas Hobbes believes that, the government but be absolute and only answerable to God if people are to end anarchy or state of nature.

These are some the negative outcomes of devolution of power, power would be difficulty to exercise. At the inception of Zuma's case both senior and private soldiers were seen in videos demonstrating together with protestors in KwaZulu Natal province. This means that, SANDF cannot deploy in KZN because they also believe that, Zuma is a subject of unjust law. The KZN has its own set of laws that governs it, and it must take the first initiative to press the distress call. The government is likely to face a series of mutinous behaviours from its military. The government erred by allowing Zuma to politicise and incite people during the five-day period granted by the court for him to voluntarily hand himself inn. Those days he effectively utilised them to play the Machiavellian political card of The Prince. The delay in imprisoning him was a big blunter whose effects we are now witnessing.

In a liberal democracy the role of the state is limited and the power of the state resides with the people. In 2017 the streets decided on Mugabe the same way it was about to Eswatini king, King Mswati. In modern politics popular revolts cannot be underestimated and knee jerk reactions are likely to cause more serious problems. Liberal democracy work effectively in a socio-political environment were citizens, institutions and political actors are mature. In countries such as the USA, the Fifth and Fourteenth Amendments of the United States Constitution limit the power of the federal and state governments to discriminate. Infact, the Fourteenth Amendment explicitly prohibits states from violating an individual's rights of 
due process and equal protection. The study cited the USA provisions due to similitudes between the two Constitution.

The research noted that, there is a knowledge gap with regard to classification of judges and how this classification might help to explain the Zuma case. Judges are first and foremost people, and as people they subscribe to different legal philosophies, the most common categorisation being that, some judges are doctrinee, historical and human rights or civil society. A doctrinee judge looks at what does the law say, historical looks at implication of the judgement to the history of the nation/society and human rights looks human rights infringements. The problem in Zuma's case might be with the individual judge and not the judicial system. At face value the judge who presided over Zuma's case is a doctrinee judge who care less about the status of the person concerned but is only concerned about what the law says. The case of Zuma is a case of a doctrinee judge who is an ardent believer of rule of law as opposed to a political or historical judge who in this case would have looked at the political history and weigh political implication before handing over a judgement. The mistake that people make is to assume that judges are the same when infact they fall under diverge categorisation.

The South African government with its limited legal provision to deal with a riotous situation is equally obligated by both the domestic and international law ensure public safety of the citizens. The state has a duty to pursue the legitimate aim of protecting national security and preventing disorderly behaviours. There are a number of case laws where the court okays initiatives by the state to protect state sovereignty and national security. In Yılmaz and Kılıç v. Turkey, 2008, since some of the slogans chanted in the demonstration in support of an illegal armed group had particularly violent connotations, the Court found that the authority pursued the legitimate aim of protecting national security and preventing disorder.

\section{Various perspectives into Zuma case}

The issues of fear for civil disobedience after a court verdict on high profile personalities is a concept not limited to South Africa. According to USA Country Report of April 2021, the USA authorities were projecting possible civil disobedience scenarios following the conviction and sentencing of former Minneapolis police officer charged in connection with the May 2020 death of George Floyd (USA Country Report: 2021). Resultantly, the USA authorities put in place measures to ensure that peace prevails. The USA intelligence had gathered that, renewed protests and rallies are possible regardless of the verdict; violence will be particularly likely in 
the event of an acquittal. While demonstrations could occur nationwide, large gatherings are most likely in major cities that saw major unrest following Floyd's death, including Atlanta, Georgia; Baltimore, Maryland; Boston, Massachusetts; Chicago, Illinois; Detroit, Michigan; Houston, Texas; Minneapolis, Minnesota; New York, New York; Philadelphia, Pennsylvania; Portland, Oregon; Saint Louis, Missouri; Seattle, Washington; and Washington, DC. Municipalities across the country will almost certainly deploy additional security forces in anticipation of the verdict (ibid). The National Guard has been deployed to Minneapolis and Saint Paul, where large crowds will likely gather near the Hennepin County Government Center, where the trial occurred. The same approach would have been done on Zuma's case, there is evidence of intelligence failure on the part of South Africa.

Section 17 of South Africa's Constitution states "everyone has the right, peacefully and unarmed, to assemble, to demonstrate, to picket and to present petitions," (Constitution of the Republic of South Africa:1999). What is happening in KwaZulu Natal does not qualify under essential elements of permissible demonstration. The South African authorities like any other state actors is mandated under the R2P doctrine to protect and promote the rights of citizens whose rights are being infringed by violent demonstrators. It must be noted that, Section 27 is a public interest law that seeks to influence, develop, and use the law to protect, promote and advance human rights.

The Court allowed restrictions if the speeches and demonstrations amount to a threat to the country's territorial integrity and national security. Thus, the threat to territorial integrity and national security justify a prohibition of the relevant assemblies (Stankov and the United Macedonian Organisation Ilinden v. Bulgaria, 2001:97). The Court has also held that the legitimate aim of "the prevention of disorder" must be interpreted narrowly (Navalnyy v. Russia, 2018:122, concerning Article 11; Perinçek v. Switzerland, 2013:146-151, concerning Article 10). However, the Court has accepted that restrictions are necessary if they serve to protect the rights of others with a view to preventing disorder and maintaining the orderly circulation of traffic (Éva Molnár v. Hungary, 2008: 34).

At face value justice and the rule of law principle was adhered to that nobody is above the law. Indeed, the principle was adhered to and Zuma is the first former president to be arrested in South Africa. In the eyes of the law South Africa's judicial system demonstrated that, it is independent and impartial. However, in the perspectives of this paper there are serious political power dynamics especially when one considers that, law is meant to sustain those in power 
'FULL STOP'. It is high time ANC know that, the law was used against ANC and not Zuma persee. The net effect of the law will destroy ANC and not the alleged 'Apartheid' judicial system. The agenda of the demonstrators speaks volumes, they want Zuma freed and Ramaphosa to resign. If it is an issue of Zuma and Apartheid judicial system, how it is it a Ramaphosa and ANC issue. The scholars, political scientists and the security sector must think beyond their nose on the Zuma issue, the regime change agenda cannot be ignored. This is politics of the laws at law, with the South African constitution and its judicial system ANC even if it wants, it cannot influence anything. This is unlike in countries were the Executive arm of the state is in total control.

The case of Jacob Zuma is a highly complex case, that requires a whole of government approach to investigate the ligament that connects rule of law, human and state security considerations. Sending Jacob Zuma to prison was the correct thing in so far as the law is concerned. Danzwa (2021) it is a huge political mistake to send Zuma to prison a sentence he would have optional served under house arrest. In matters like this the truth is politics overrides the law. For the sake of peace and stability in the country it was unwise to send Zuma to prison considering his age, political clout, COVID 19 pandemic because anything adverse that would happen to him whilst in prison, there will be political pandemonium in South Africa. The South African government should also consider the perspectives of both siting and former African Union, heads of state. Whilst it is a South African internal matter the person concern's stature in African Union cannot be ignored. This, is further compounded by the nature of the crime concerned.

World over the basic principle of law is that, nobody is above the law and Zuma is no exception. The concern comes when its application is being racially, tribally and politically interpreted. The violent demonstrations are a threat both state and human security. There is rampant, civil unrest, destruction of property, loss of life, violation of the WHO guidelines were protestors are not maintaining social distancing. In this COVID 19 era the South African government must adhere to the pacta sunt servanda doctrine by adhering to WHO guidelines. The right to demonstrate cannot prelude the global security of COVID 19 and the declaration of national lockdown by the South African government itself. Examples can be drawn from the past, in the USA, the government in the name of democracy allowed citizens to demonstrate under the banner \#Blacklivesmatter. In the aftermath of the campaign COVID 19 cases shot drastically, lives were lost and mainstream economy was affected. 
The delays in the deployments of the whole of the security sector to quell down the demonstrations is highly worrisome. In the European Court of Human Rights, paragraph 2 of Article 11 and in a constitutional case of Ezelin v. France, 1991, Navalnny and Yashin v. Russia, 2014 the court authorised 'restriction' on the right to demonstrate especially when the demonstration is not peaceful (The European Court of Human Rights:2014). The violent nature of the demonstration requires the deployment of both police and the local South Africa National Defence Forces (SANDF). Article $11 \S 2$ of the Convention lists legitimate aims which an interference should pursue, national security or public safety, the prevention of disorder or crime, the protection of health or morals, or the protection of the rights and freedoms of others (ibid). the government of South Africa should apply this doctrine, given the surge in COVID 19 cases. South Africa's neighbours are grappling with corpses of citizens who would have succumbed to COVID 19. The issue of reckless behaviours by protestors is a national security issue not only in South Africa but also on South Africa's neighbours.

In the case of Zuma, it was prudent for the judge to delay issuing the warrant of arrest on Zuma till the situation improves. The government was aware that the judgement was likely to cause civil disobedience, through popular revolts. In Zimbabwe when jailing Pastor Evan Mawarire pointed to civil disobedience the state made a wise decision to free him and proceeded by way of summons. With the history of South Africans any perceived Apartheid judicial proclamation was advertently and inadvertently a threat to both national and human security. The case of Zuma had gone beyond legal matter it is now a national and human security issue. The next thing is the call for the resignation of President Ramaphosa. Political parties and South Africa's erstwhile enemies are now taking advantage of the situation to weaken its economy and the ANC. Currently, there are fissures within ANC on the manner in which Zuma's was handled. Whilst the ANC is trying to distance itself from the undue influence of Zuma's case, in the court of public perception which has now taken a centre stage and occupied the streets. In the eyes of court of public opinion, President Ramaphosa and some key ANC members are behind the perceived Apartheid judgement against Zuma.

The reverse political engineering is at play in South Africa and there are two outcomes, Zuma political sympathy will be transferred to Malema. The visit by Malema to Nkandla where he met and shared a cup of coffee with Zuma was a political grandmaster posture by Malema. Zuma in his last days, his speech sounded very revolutionary like that of Malema. With the publics and social media portraying ANC and Ramaphosa as anti-Zulu, its political capital dwindles. The affected provinces by these disturbances are ANC's political strongholds and 
the situation remain unchanged the ANC will soon be a shell and the whites will take full charge of South Africa.

SADC should also act in the South African situation, the geostrategic political philosophy, the Regional Security Complex theory and Kent's political and security ideas requires SADC to create projections of likelihood scenarios is South Africa is to implode politically. South Africa is SADC's important economic hub for SADC and most SADC member states have their citizens in South Africa. This is not a South African issue given that, popular revolts are often contagious. The situation in South Africa can cause the reconfiguration of SADC political order as was with the case with Arab spring. Currently, ESwatini, Mozambique and South Africa are facing highly complex internal problem with a lot of hidden variables. SADC must also take into account the role of external hand hence the disturbances in SADC can be taken advantage of the region's erstwhile enemies.

There are two options left for South Africa, one is to ensure that, Zuma's application for the rescission of his 15-month prison sentence in the Constitutional Court succeeds. In any country the President has the power of pardon in terms of Section 82(1) of the Constitution. In the Constitutional Court of South Africa President of the Republic of South Africa and another v Hugo Case CCT 11/96 Decided on 18 April 1997, the court noted that, the grant of a pardon is a matter purely within the discretion of the President. It was also noted that, whilst the president acted unfairly his decision was discretional. Also, to note, the president can do remission of sentence on an individual basis in the light of their special circumstances. President Ramaphosa can use this legal provision to pardon or remission of the sentence. Under this principle the President can take advantage of COVID 19, his health, age, liberation history and the state security considerations to pardon him. The events in KwaZulu Natal is enough proof that his continued stay in prison is a national security issue. The more people are gathering enmasse without any masks or maintaining social distance the more the disease is spreading. Health security is a very serious human and state security issue especially when considering that, the $3^{\text {rd }}$ wave has high mortality rate. Remedial actions must be taken by releasing one person Zuma from for the purpose of peace to enable the government to respond to COVID 19 pandemic. The balance of law principle must be applied.

The situation is damaging human and state security more than it is benefiting the law. The incarceration of Zuma had infact increased his political capital and he soon going to be made the second Mandela. The whole saga is an indirect political campaign for Zuma. The purpose 
of a jail is to rehabilitate and reform the offender of the law but in this case the opposite is true. He deliberately played the victims card, by delaying to hand himself inn prompting the government to over deploy to arrest a former president. The government scored against itself, political under the guise of applying the rule of law. The series by speeches by Zuma after he was sentenced is a political fire that is going to consume South Africa. The South African judicial system erred by giving Zuma time to mobilise. In the USA, Trump made similar political manoeuvres when he led the invasion of the Capital Hill. Trump nearly turned the USA into a banana republic resulting in timely intervention. The South African government's delay to act, is costly from a human and security point of view. The volatile situation has since gone viral, the demonstrators, have taken to burning tyres, blocking roads, and looting stores and are demanding that the former president released from jail. Whilst the government is busy procrastinating and engage in media tactics where state media is not airing the events in KwaZulu Natal social media is busy pushing volumes of conspiracy theories, fake news, media propaganda. With the social media and globalisation states must begin to realise that, media blackouts are nolonger tenable. Media globally, is now fluid and uncontained. Strategic communicators are key in image repair and image building; hence states must invest in strategic communication for behaviour and attitude change in crisis situations.

Samora Machael argued that for a nation to live a tribe must die, Zuma failed to let the tribe in him to die. Zuma continued to link himself to the Zulu tribe instead of him to be identified with the whole of South Africa as a national figure. Now that Zuma like many other serving and former presidents in Africa, they continued to be linked with their tribes and culture. In this case the Zuma judgement, it is nolonger a Zuma issue but a case of ANC and the Judiciary against the Zulu people. These are effects of a leader who fail to let the tribe die upon assuming public office. Zuma throughout his tenure as the president he never took a foreign vacation. He was always in KwaZulu Natal and never missed any Zulu cultural festival and he would wear their attire and dance like everyone else. In Zuma they see a true Zulu who is not ashamed of where he came from. In a book Dare Not Linger by Madiba, Zuma is an expert of balance of power politics and had the wisdom to keep the end goal alive. In addition, Zuma seemed more at ease among his own tribe.

In a 2018 editorial headline, The dangers of Zulu nationalism, City Press editor Mondli Makhanya argued that, the Inkatha Freedom Party controlled by Bantustan of KwaZulu Natal is composed of generation of young people indoctrinated by a non-examinable subject called ubuntu-botho (Makhanya:2018). At the core of this doctrine is violent nationalism making the 
Nkandla situation more complex that what misses the eye. The doctrine teaches children to pursue the dream of the restoration of the Zulu empire. This is the same manner Mthwakazi is advancing the restoration of Ndebele kingdom in Zimbabwe. The Zuma case presented an opportunity for the Zulu to demand cessation and restoration of the Zulu empire. The Zulu have tested political power through Zuma and they will do everything to ensure that he is released from prison. His arrest and detention demeaned their tribal invisibility posture. This aspect has a spill over effect to countries with Zulu remanences.

Whilst the issue of Zulu nationalism was at speculative level, Ramaphosa on 11 July 2021 addressed a state of the nation address where he blindly and blatantly accused the Zulu for the mishap in KwaZulu Natal. "It is a matter of concern to all South Africans that some of these acts of violence are based on ethnic mobilisation. This must be condemned by all South Africans at all costs as we are a nation committed to non-racialism and non-tribalism that is underpinned by the diversity and unity of all the people of South Africa, whatever their language, culture, religious beliefs and race," said Ramaphosa (SABC:2021). The statement by Ramaphosa is rather a reckless statement, that might fuel tribal wards in South Africa. The situation is fast deteriorating from being a purely a legal matter to tribal, political, criminal and popular revolt.

\section{Hidden variables to Zuma issue}

There is evidence of applied Marxist-Leninism they have destroyed billion worth of goods and the majority of insurance companies are white owned and will struggle to pay for the damaged properties. The situation has degenerated into a war between property owners most whites and the protestors. However, when the violence started it was war against fellow black's business. The situation has turned racial whites against blacks. The white soldiers deployed are making a series of recorded reckless statements that they are ready to kill the blacks because their interests have been directly affected. The videos resonated Malema who often use parliament platforms to castigate white capital monopoly. The blacks versus white monopoly has always been a time bomb for South Africa with South African beginning to reflect on their socioeconomic conditions. The situation has degenerated into a very complex scenario of business owners versus looters.

The South Africans are now ready to dump key pillars of South African constitution, popular democracy and justice system. The streets are the one determining and applying tenants of democracy. The question is will South Africa recover from the damage inflicted on its 
democracy and the justice system. Perhaps the USA strategy of using media to do damage repair after Trump abrogated key pillars of the American democracy by instigating the invasion of the Capital Hill.

The law of proportionality would have been used here. The money stolen by Zuma combined is perhaps far less that the monies incurred due to loss of property, arson, looting, disturbing the flow of business, monies injected in managing peace and order, the flora and fauna disturbed, the image and integrity of the state affected. On this basis, therefore, it is unwise to arrest Zuma. There is now national security and human security implication in only trying to impose partly 15 months jail term. The logic for continued application of the rule of law becomes quite baseless. The court has also been undermining and for a judgement to stand it must pass the credibility and undue influence test. Whether its judgement was credible or otherwise in the public opinion its political rule of law.

The game park strategy, this is a new political culture where fence of game park is cut will animals released to aid Zuma demonstrators. The situation is posing more and more nontraditional elements. The fence Hluhluwe Game Reserve was cut off and the wild animals are now roaming the streets. The human security is now in danger with the wild animals that were released. Endangered animals like rhino and elephants are now at a greater risk with poachers. President Ramaphosa erred by reducing the Zuma issue to wholly tribal, there are non-tribal elements like crime as is being seen in massive looting of both formal and informal business in KwaZulu Natal and many other provinces.

The constitution of South Africa is emblematic of the traditional constitutions in that it binds the state and not the private citizens. The constitution does not have a direct application to private citizens. In cases of civil disobedience such a constitution is dangerous because, private actors are not bound by constitutional rights unless the conduct of those actors qualifies as 'state action'. This means that, the South African government must first qualify, that the demonstrators qualify to be state actions like posing serious threats to human and state security. This, means the government must wait for the problem to manifest before for example it can deploy SANDF. The delay by the South African authorities to deploy the military to protect the civilian population and the business community works against the R2P doctrine and the human security, that a state must protect and promote the rights of its citizens.

Nyerere argued that, seek yeee the political kingdom and everything else will follow. In South Africa whilst it attained political independence the judiciary and the economy remained in the 
hands of the Apartheid South Africa. The Zuma judgement might mark a second wave of political socialisation where South Africans will reflect on the quality of their independence. The sentiments by Malema will begin to have vindication that, South Africa is still a colony. Fanon believed in the supremacy of violence to bring the desired change. The South Africans might be fighting a just cause to eradicate neo-Apartheid the same way Zimbabwe adopted the land reform to correct a historical imbalance. In Mozambique the insurgency groups are fighting for developmental imbalances and the failure to include the locals in mainstream economy. The terror or insurgency groups might take advantage of the situation to cause mayhem and pitch themselves. The government must cease to adopt the wait and see approach because soon the situation will be volatile and out of order.

The situation might not be as tense as it was going to be had Zuma respect the Zulu king in his political mischief. Emeritus Prince Mangosuthu highlighted a very important point that, Zuma mobilised the amabutho without the incoming king's approval. The king since he did not sanction the act, can be used to resolve the conflict by calling his regiments to order. The king would naturally be respected than even deployment of security to manage the situation. This gap between the king and Zuma has not been fully exploited towards peace and security in line with the human and state security doctrine.

There is a human security dimension, the history of violence in Nkhandla is the history of active participation by the Abahlali Base Mjondolo, the shack-dwellers movement fighting for the right to decent housing and food. The Zulu are fighting for freedom and other elements taking advantage of the volatile situation to satisfy their human security needs through looting of basic commodities. The human security dimension of opportunists is an area being ignored in Zuma's case. These people also participate in violent demonstration to show their solidarity posture with the 'vicious' amabutho regiments. There is hidden variable to why non-Zulu elements are participating in these skirmishes.

It is not about Zuma anymore but a human security issue. Frustrated people, hungry people in lockdown, unemployment all they want is a reason to start protesting. In the past decade South Africa experienced a surge in violent demonstrations and xenophobic attacks linked to human security hence the Zuma case only acted like the Sarajevo assassination which sparked a revolution. The South African authorities must not undermine the threat emanating from human security, Eswatini is unstable due to human security consideration. There was political reconfiguration in the Arab world due to mishandling of the human security dimension. 
Meanwhile those whose businesses are being affected will force the government to act on protestors. The skeletons of unequal distribution of the economy, high illiteracy rate and the failure by SADC to silence the guns by 2020 are the skeletons that are beginning to tumble. In Mozambique's Cabo Delgado weak demobilization, demilitarisation and reintegration (DDR) is now a threat to regional security. In case of South Africa, citizens have unlicensed guns and any uncalculated response can trigger a full-scale civil war.

There is also a hypothesis that, Zuma was fighting the ANC from within and was propping up his son Edward Zuma into ANC mainstream politics. The argument being that, whatever that is happening its internal ANC politics. If this is ANC factional fights the Zulu will influence the recall of Ramaphosa and replace him with a Zulu cadre. The president might be living on borrowed time, considering that he is still battling the recall by the ANC Secretary General. The Ramaphosa; mustgo' being pushed by protestors points to a premeditated agenda.

Protecting the advance to peace, it not about succeeding winning a case but at what price. The death of Zuma's brother can spark outrage due to social media weaponization by private actors and opposition political parties who are using the Zuma issue for political mileage. The death of Bouazizi led to the Arab spring and the protestors are now linking his death to the arrest of his brother. The medical history of long illness is being slowly ignored because the recipients have an agenda setting and agenda loading. In their agenda to fight for Zuma they are now loading into their agenda hate speech, propaganda and conspiracy theories.

The issuance of a statement by Justice and Correctional Services necessary and timely that, Zuma is not getting preferential treatment in Jail, in an environment where the protestors are concerned about his welfare in prison. This shows that the department need to be educated on strategic communication skills. Reckless statements and leaking of Zuma's detention and prison photos is a serious political miscalculation that can impede state and human security.

The role of agitated foreigners who crossed to South Africa in anticipation of sustainable livelihoods only to be othered and subjected to xenophobic attacks. The violence presents an opportunity for them to loot and also to fight for a better South Africa since they do not harbour any prospective of turning to their countries anytime soon. Since political determination is through the ballot box a key aspect, limited to citizens the only means for to have their rights heard is through participating in political demonstrations. Whilst the law of South Africa regard either foreigners or illegal immigrants in their country as non-South Africans, the majority of these foreigners and illegal immigrants most of whom have more than two decades, identifies 
themselves with South Africa than their countries of origin. Thus, most illegal immigrants and foreigners, regard themselves as both de facto and de jure citizen. Streets demos presents an opportunity for the non-voting constituency push for their human security needs, hence there is combination of political agitation and looting.

\section{Conclusion}

The Zuma issue will have detrimental effect to the South African economy after the government failed to mitigate and protect the vulnerable business people whose wares are being destroyed. The state had failed its human security duty of protecting the vulnerable civilian population. Meanwhile, the state has lost the plot to do damage control on the allegation that, Zuma's arrest and jailing is a political plot. The situation requires a balanced reaction which takes into account, rule of law, human security and state security in light of hidden variables to the Zuma saga. In-light of future projections, Ramaphosa would be forced to resigned and replaced by Lindiwe Zulu who is more appealing to the riotous situation, SADC will be affected interms of geostrategic configuration. South Africa is SADC's economic and political hegemony and powerhouse. The disturbances in South Africa are likely to have a serious spill over effect. On health security, the demonstration has exposed citizens to the vagaries of the COVID 19 pandemic. The demonstrators were seen in various social media videos violating COVID 19 WHO guidelines. In this whole political configuration Julius Malema's political dividends are going to grow tremendously and his strategic political foresight of visiting Zuma and shared a cup of coffee is going to pay dividently. Zuma in his last speeches became Malema's prototype interms of harsh political tone. The South African government lacked strategic foresight on Zuma's last speeches after his conviction. 


\section{References}

Constitution of the Republic of South Africa, (1999).

Mondli Makhanya (2018), City Press editor, The dangers of Zulu nationalism

The European Court of Human Rights, paragraph 2 of Article 1, 2014

Stankov and the United Macedonian Organisation Ilinden v. Bulgaria, (2001: 97)

USA Country Report of April 2021

In the Constitutional Court of South Africa President of the Republic of South Africa and another v Hugo Case CCT 11/96 Decided on 18 April 1997

Y1lmaz and K1lıç v. Turkey, (2008) 